\title{
STUDENTS MATHEMATICAL COMMUNICATION SKILLS ON COOPERATIVE LEARNING OF TGT TYPE TO SET MATERIAL
}

\author{
Meinar Yuari Salsabil, Siti Inganah, Yus Mochamad Cholily \\ Department of Mathematics Education, Faculty of Teacher Training and Education \\ University of Muhammadiyah Malang \\ meinarojolamban@gmail.com
}

\begin{abstract}
This study aims to describe students' mathematical communication skills both oral and written. The communication ability is observed through the application of cooperative learning model type TGT for set theory. The research design was qualitative descriptive. The subjects of the study were 17 students of class VII-B. The learning material were lesson plan, discussion group, game group, worksheet, game question, and written test. The research instruments were observation sheet of teacher activity, written and oral mathematical communication ability. The results of the study at the first meeting showed that the ability of oral mathematical communication had sufficient category and written had low category. The second meeting of oral mathematical communication skills had sufficient category and written was better than before. Oral mathematical communication improved at the third meeting, while written in the low category. The fourth meeting was increased in the ability of oral and written mathematical communication, for high oral mathematical communication and written with high category as well. The students' mathematical communication skills from the first to fourth meetings had increased. The average overall ability of oral and written mathematical communication was sufficient.
\end{abstract}

Keywords: Mathematical communication ability, cooperative learning model of TGT type

\section{INTRODUCTIONS}

Cooperative learning is one of the learning models that can bring togetherness of the students diversity. Cooperative learning refers to the student learning method of small groups work and help each other in learning process (Riyanto, 2010: 267). The learning involves a group of four students with different abilities. An active students participation in learning process is supported by communication skills. The communication ability development is to give students the opportunity to explain and argue both oral and written, asking or answering questions from friends or teachers, and discussing on each small study group and classroom learning group (Suryadi, 2009: 166). Good student communication skills can be seen from student activities in telling problem solving ideas to teachers and other students, providing mathematical 
reasons for the problem-solving, and speaking clearly on the explanation of mathematical concepts.

The observations were done in grade VII Darussalam Junior High School Lawang indicated that a small proportion of students made in the active learning class. The students did still not maximize in expressing opinion, asking questions about mathematical concepts that had not been understood, and responding to other students' mathematical ideas. These conditions were in accordance with the results of interview with teachers of mathematics class of VII-B Darussalam Junior High School Lawang that students' communication skills were low in math learning. The students who actively communicated were 4 students or $22 \%$ of the total number of 18 students. A total of 4 students were able to express ideas of mathematical concepts and explain the mathematical steps of working on problems with clear language. The rest of the students have not been able to express problem-solving ideas, discuss problem solving, or provide coherent reasons in the answer to the description.

Learning model that can be applied in junior high school is cooperative learning model of TGT type (Teams Games Tournament). The TGT learning type focuses on the students' level of ability and uses academic game to encourage student motivation. Each student is placed in a group of low, intermediate, and high-ability students. Each group is set to have a balanced member composition (Warsono and Hariyanto, 2013: 165). The TGT learning type assigns each group member to learn the material first along with the other members, then they compete on behalf of the group through academic games. The value they get from this game will determine the score of their respective groups (Huda, 2016: 117). Application of this TGT learning type is expected to develop students' mathematical communication skills both oral and written.

The research result of Gusniawati and Baskoro (2015) showed that after applying cooperative learning model of TGT type, the students were eager in following the learning process and increasing the students' learning outcomes in math subjects. Fahradina's (2014) research of mathematical communication ability and student learning independence of Junior High School showed that communication ability and student learning independence were better when using group investigation type of cooperatif learning model instead of using conventional learning model. 
The problem which was chosen by the author was about students' mathematical communication skills on cooperative learning of TGT type. The reason why the writer selected that problem was to describe how the mathematical communication skills of students both oral and written with application of cooperative learning of TGT type. The application of that learning was expected to improve students' mathematical communication skills.

\section{RESEARCH METHOD}

Qualitatif descriptive research for this research was about students' mathematical communication ability. Observation was used to get data of student's mathematical communication ability and direct observation was used to this research. The research subjects are observed using the observation indicator.

This research was conducted on March 15-25, 2017 of academic year 2016/2017 consisting of four meetings. The research subjects of this study were 17 male students of VII-B Darussalam Junior High School Lawang. The activities for each meeting are arranged to facilitate the research conduction. The research procedure was preparation, implementation, and reportation.

The implementation of learning which was conducted by the teacher was observed the teacher activities by using observation. The data of students' mathematical communication skills were orally collected using observation instruments when the students discussed in group. The ability of students' mathematical communication in writing was observed by using a written test. The documentation used in this research was pictures of activities to describe student activities and answers.

The Qualitative analysis is a technique used to analyze data in this study. The planning of TGT type for set theory is described based on the written learning instrument. Application of cooperative learning of TGT type is described based on observation instrument of learning implementation. The describing of oral mathematical communication uses the circumstances in the classroom when students discussing. The students' written mathematical communication skills are described in accordance with student answers.

\section{RESEARCH RESULTS AND DISCUSSION}

This research was conducted on March 15-24, 2017 consisting of 4 meetings. The lesson plans which had been arranged in this research on cooperative learning of TGT 
type were learning implementation plan for every meeting, discussion group between students which consist of 3-4 students, student worksheets for every meeting, academic tournament table with representatives from discussion group, academic game question for each tournament table and a matter of written test for each student. The implementation category of cooperative learning of TGT type in the mathematics learning of the set material is shown in Table 1.

Table 1: The Implementation of Cooperative Learning of TGT Type

\begin{tabular}{cccccc}
\hline Meeting & I & II & III & IV & Average \\
\hline Percentage & $81.2 \%$ & $87.5 \%$ & $87.5 \%$ & $93.8 \%$ & $87.5 \%$ \\
\hline Category & Good & Goo & Good & Very Good & Good \\
\hline
\end{tabular}

The implementation of cooperative learning of TGT type at the first meeting was $81.2 \%$ with good category. The teacher left some activities, so the learning was still not perfect. The implementation of the second lesson was better than the first meeting because the teacher had better preparation to do the learning process. The learning steps that have been applied at the first meeting make it easier for the teacher to take the second step. The second learning reached a good about $87.5 \%$ level of implementation.

The teacher had better preparation for the third lesson so that the students were eager to follow every step of learning process. The implementation of cooperative learning of TGT type at this meeting was $87.5 \%$ with good category. The skills of teachers during the first, second, and third meeting make the teacher mastery of the learning model. Very good result was achieved by teacher in the implementation of learning at the fourth meeting with percentage of $93.8 \%$.

The lessons learning during the four meetings were already obtained the data of students' mathematical communication skills. The Categories of mathematical communication ability of VII-B students oral and written were shown by Table 2 .

Table 2: Student Mathematical Communication

\begin{tabular}{ccccccc}
\hline \multirow{2}{*}{ Pertemuan } & \multicolumn{2}{c}{ Tulis } & \multicolumn{2}{c}{ Lisan } & \multicolumn{2}{c}{ Tulis dan Lisan } \\
\cline { 2 - 6 } & Persentase & Kategori & Persentase & Kategori & Persentase & Kategori \\
\hline I & $63,3 \%$ & Rendah & $71,7 \%$ & Cukup & $67,5 \%$ & Rendah \\
\hline II & $74,6 \%$ & Cukup & $71,7 \%$ & Cukup & $73,5 \%$ & Cukup \\
\hline III & $68,6 \%$ & Rendah & $78,6 \%$ & Cukup & $73,6 \%$ & Cukup \\
\hline IV & $83,8 \%$ & Tinggi & $82,8 \%$ & Tinggi & $83,3 \%$ & Tinggi \\
\hline Rata-rata & $72,6 \%$ & Cukup & $76,2 \%$ & Cukup & $74,5 \%$ & Cukup \\
\hline
\end{tabular}


The first meeting of the class was seen quite active in the discussion, but it was not used to apply the knowledge during the discussion on the worksheet. The students' mathematical communication of written at the first meeting was $63.3 \%$ with low category. Orally, the mathematical communication of the students was better than written, that was got $71,7 \%$ with enough predicate. The second meeting of students' mathematical communication of written rose to $74.6 \%$ with sufficient category. The students have started to fill the skill of solve the problem solving through cooperative learning model of TGT type, so as to create good written mathematical communication.

The oral communication of students at the third meeting was experienced a pretty good increasing, that was $78.6 \%$ with enough category. This happened because the students at that time seemed eager to follow the lesson. The spirit of students was seen actively by discussing with group members. Student activity in discussions has not an impact on the ability of written communication. The students' mathematical c o m m u n i c at i o n ability of written has $68,6 \%$ with low category. The fourth meeting of students discussed well. This happened because students already understand how to make cooperative learning of TGT type steps. The learning run smoothly from the beginning until to the end of the meeting. The Students were more critical in discussing with members of their group. Oral communication got percentage of $82.8 \%$. The students' activity in discussing had a good impact on students' mathematical communication ability of written at this fourth meeting, which was $83.8 \%$ with good category.

Good learning activities have an impact on student learning development in accordance with Epong Utami (2013) research that cooperative learning of TGT type performed with good and structured steps could improve the quality of student learning. The research was also in line with Gusniawati (2014) research that cooperative learning of TGT type could improve student learning outcomes through students' activities in discussion. The whole series of learning that have been done by researchers in class VIIB on the set material was going well so as to increase students' activity in learning process.

The improvement of mathematical communication skills through cooperative learning which accordance with Fahradina's research (2014) that cooperative learning of Group Investigation type could improve students' mathematical communication. Students who learned to use cooperative learning models have better mathematical communication 
skills than students who learned to use conventional learning models. The ability of mathematical communication in cooperative learning of TGT type toward set theory in class VII-B was commonly seen a quite good.

\section{CONCLUSIONS}

The research of students' mathematical communication ability on cooperative learning of TGT type toward set theory in class VII-B Darussalam Junior High School Lawang Malang has reached the final stage. The conclusions that can be drawn from the research are as follows.

1) The plans that have been done by teachers to implement the cooperative learning of TGT type were learning implementation plan, discussion group division, student worksheet, academic tournament table, tournament problem, and individual written test.

2) The implementation of cooperative learning of TGT type to the learning of subject matter in class VII-B Darussalam Junior High School was conducted based on learning implementation plan gave positive impact to the students. This can be seen from students' activeness in group discussions and academic games. The academic games uplift the students' spirit in learning because of the competition among the discussion groups.

3) Students' mathematical communication ability on cooperative learning of TGT type has developed during the first to last learning process. The mathematical communication of the students orally envolves according to the liveliness of the students discussion while in written ability shows the progress of the written test results.

The description on the result of research, discussion, and conclusion about student mathematical communication research on cooperative learning of TGT type for set theory in class VII-B Darussalam Junior High School Lawang has been presented. The researcher gives some suggestions that need to be considered as follows:

1) Learning activities using cooperative learning model of TGT type can be used as an alternative for teachers to be applied in mathematics learning because it can support students' mathematical communication skills

2) Other researchers or teachers who will apply cooperative learning models of TGT type can be further developed in other mathematical material except set theory. 
3) This research only examines the students' mathematical communication ability, so it can be used as input material for other researchers by examining other mathematical aspects.

\section{REFERENCES}

Fahradina, N., \& Ansari, B. I. (2014). Improvement of Mathematical Communication Skill and Self-reliance of Junior High School Students by Using Group Investigation Model. Mathematics Didaktic Journal, 1(1), 54-64.

Gusniawati, E., \& Baskoro, E. P. (2015). Application of Cooperative Learning Method Teams Games Tournaments Techniques in Efforts to Improve Student Learning Outcomes in Mathematics Subject Sub Subject Matter of integers. EduMa, 4(1), 113-124.

Huda, Miftahul. 2016. Cooperative Learning. Yogyakarta: Pustaka Pelajar.

Moleong, Lexy J. 2005. Qualitative Method Research. Bandung: Rosda.

Permata, C. P., Kartono, K., \& Sunarmi, S. (2015). Analysis of Mathematical Communication Skills of Grade VIII Junior High School Students on TSTS Learning Model with Scientific Approach. UNNES Journal of Mathematics Education, 4(2).

Riyanto, Yatim. 2010. New Paradigm of Learning. Jakarta: Prenada Media.

Sugiyono. 2013. Qualitative and Quantitative Research Methods. Bangdung: Alfabeta Suryadi,

Didi. 2009. Educational Sciences and Applications. Bandung: Imtima.

Utami, Epong. 2013. Application of TGT Learning Model Through Realistic Mathematics Approach as Efforts to Increase Learning Outcomes in Class IV A Material SDN-P Bantarjati 9 Bogor Teaching Year 2012/2013. Dompet Dhuafa Education Journal, 01 (03): 48-58.

Warsono \& Hariyanto. 2013. Active Learning. Bandung: Remaja Rosdakarya. 